\title{
Characterization and fatty acid profile analysis of oil extracted from unexploited seed of African star apple (Udara)
}

\author{
Kingsley Ozioma Omeje ${ }^{1, *}$, Okechukwu Kalu Iroha ${ }^{1}$, Affiong Asuquo Edeke ${ }^{1}$, Henry Chimezie Omeje ${ }^{2}$ \\ and Victor Onukwube Apeh ${ }^{1}$ \\ ${ }^{1}$ Department of Biochemistry, University of Nigeria, Nsukka, Enugu state, Nigeria \\ 2 Department of Biochemistry, University of Port Harcourt, Choba, Rivers state, Nigeria
}

Received 14 August 2018 - Accepted 20 February 2019

\begin{abstract}
This study sought to characterize the phyto-oil extracted from an unexploited seed of African star apple (Udara) using soxhlet extraction method, normal hexane was used as the solvent at $67^{\circ} \mathrm{C}$ for $4 \mathrm{~h}$. The percentage oil yield was $23.8 \%$. The extracted oil was liquid at room temperature, pleasant sweet smell with honey-like colour. The oil physicochemical properties such as acid value, peroxide value and saponification value were $17.41 \pm 0.43 \mathrm{mg} / \mathrm{KOH} / \mathrm{g}, 57.74 \pm 2.77 \mathrm{meq} / \mathrm{kg}^{-1}$ and $236.341 \pm 6.80 \mathrm{mg} / \mathrm{KOH} / \mathrm{g}$, respectively. Also, free fatty acid of $8.75 \%$ and iodine value of $29 \pm 0.16 \mathrm{mg} / 100 \mathrm{~g}$ were obtained. The identified fatty acids present included n-hexadecanoic acid (7.55\%), 13-hexyloxacyctri-dec-10-en-2-one $(1.19 \%)$, oleic acids $(30.21 \%)$, octadecanoic acid $(5.28 \%)$, hexadecanoic acid $(2.37 \%)$, undecylenic acid (40.33\%), 9-octadecanal (7.09\%), and 9, 17-octadecadienal (5.98\%). The properties of oil extracted revealed that the seed is a good source of oil which could be employed for industrial purposes.
\end{abstract}

Keywords: African star apple / fatty acid analysis / GC-MS / phyto-oil / unexploited seed

Résumé - Caractérisation et analyse du profil en acides gras de l'huile extraite des graines non exploitées de l'African star apple (Udara). Cette étude visait à caractériser l'huile extraite d'une graine non exploitée d'un arbre appelé African star apple (Udara), par la méthode d'extraction au Soxhlet; de l'hexane normal a été utilisé comme solvant à $67^{\circ} \mathrm{C}$ pendant $4 \mathrm{~h}$. Le pourcentage de rendement en huile était de 23,8\%. L'huile extraite était liquide à température ambiante, de couleur miel et dégageait une agréable odeur. Les propriétés physicochimiques de l'huile telles que l'indice d'acide, l'indice de peroxyde et l'indice de saponification étaient respectivement de $17,41 \pm 0,43 \mathrm{mg} / \mathrm{KOH} / \mathrm{g}$, de $57,74 \pm 2,77 \mathrm{meq} / \mathrm{kg}^{-1}$ et de $236,341 \pm 6,80 \mathrm{mg} / \mathrm{KOH} / \mathrm{g}$. Des acides gras libres à hauteur de $8,75 \%$ et un indice d'iode de $29 \pm 0,16 \mathrm{mg} /$ $100 \mathrm{~g}$ ont également été mesurés. Les acides gras identifiés présents comprenaient l'acide n-hexadécanoïque $(7,55 \%)$, le 13-hexyloxacyctri-déc-10-ène-2-one $(1,19 \%)$, les acides oléiques $(30,21 \%)$, l'acide octadécanoïque (5,28\%), l'acide hexadécanoïque (2,37\%), acide undécylénique (40,33\%), le 9octadécanal $(7,09 \%)$ et le 9,17-octadécadiénal (5,98\%). Les propriétés de l'huile extraite ont révélé que la graine est une bonne source d'huile pouvant être utilisée à des fins industrielles.

Mots clés : African star apple / analyse des acides gras / GC-MS / huile / semences inexploitées

\section{Introduction}

Fats and oils (lipids) are one of the important macromolecules of the living organisms. Its importance span from energy generation, through membrane formation and maintenance to the biosynthesis of other essential compounds in the body. Any kind of changes in lipid metabolism

\footnotetext{
*Correspondence: kingsley.omeje@unn.edu.ng
}

can result in modification of membrane composition and subsequently in changes in its permeability (Orsavova et al., 2015). They consist of mixtures of organic molecules, which are mainly triacylglycerols, diacylglycerols, monoacylglycerols, free fatty acids and other minor components such as phospholipids, phytosterols, tocopherols and tocotrienols and hydrocarbons (Hamm et al., 2013). They could be classified as saturated (no double bonds), monounsaturated (one double bond), and polyunsaturated fatty acids (multiple double bonds) (Enechi, 2001). 
Plant seeds have been used since antiquity as sources of vegetable oil (Adebayo et al., 2012). Vegetable fats and oils are lipid materials derived from plants, which are solids and liquids at room temperature, respectively (Adebayo et al., 2012). Some major oilseeds as enumerated by Ononogbu (2002) are soybeans, groundnuts, cottonseeds, sunflower, rapeseeds, oil palm, and coconut. These plants have been developed to maximize their oil production capacity, as they are traditional and economic products of most tropical and subtropical countries (Ononogbu, 2002).

They are some unexploited source of phyto-oil, which could be alternative to the conventional plants. One of such plants is African star apple (Chrysophyllum albidum). There is dearth of information to any usefulness of the seed of African star apple (Chrysophyllum albidum).

African star apple (Udara in Igbo) belongs to the family of Sapotaceae which comprises of about 800 species (Ehiagbonare et al., 2008). It is an evergreen tree and can grow up to $40 \mathrm{~m}$ high and about $2 \mathrm{~m}$ in girth. It has a straight and long fluted bole with small buttress at the base (Adebayo et al., 2012). The fruit when ripe is ovoid to sub-globose, and contain three to five seeds which are not eaten. The seeds are dark brown or blackish, obliquely ellipsoid to obovoid, up to $2.8 \mathrm{~cm}$ long and $1.2 \mathrm{~cm}$ wide; its coat are hard, bony, shiny and dark brown and when broken reveals white coloured cotyledons (Adebayo et al., 2012).

African star apple (Chrysophyllum albidum) is one fruit of great economic value in tropical Africa due to its diverse medicinal and food uses (Adebayo et al., 2012). In recent times, the plant has become a crop of commercial value in Nigeria (Oboh et al., 2009). The seeds are been discarded in discriminately after the consumption of the succulent fruit. In this research, oil was extracted from the unexploited seed of African star apple (Chrysophyllum albidum), characterized and the fatty acid profiled using gas chromatography-mass spectroscopy. The extraction of oil from this agro waste would lead to the eradication of the waste from the environment, thereby creating a clean environment. Also, the oil produced could be applied in various aspect of industries. Being a non-edible material, it is a good oil feed stock since there would not be any debate as regards the creation of food scarcity due to its usage in oil production. Similarly, the oil could be used in the production of biodiesel because it is rich in fatty acids.

\section{Materials and methods}

\subsection{Apparatus}

Gas chromatography-mass spectroscopy (GC-MS-QP2010 plus Shimadzu, Japan), n-hexane and other chemicals were products of Sigma-Aldrich, USA.

\subsection{Plant sample collection and preparation}

Seed of African star apple (Chrysophyllum albidum) were picked from its natural habitat in Ikem village of Nguru community of Nsukka LGA, Enugu state, Nigeria. The seeds were de-shelled and cotyledons were sun dried for twelve days. The dried cotyledon was ground using electric blender.

\subsection{Seed oil determination using soxhlet extraction}

Milled sample weighing $20.86 \mathrm{~g}$ was placed in a thimble before adding the solvent (hexane: chloroform) in a ratio $50: 50 \mathrm{ml}$ in the flat bottom flask. The set-up was heated at $67^{\circ} \mathrm{C}$ for $4 \mathrm{~h}$. After the extraction processes, the oil residue was exposed to the atmosphere and the solvent allowed to evaporate and oil extracted was quantified.

\subsection{Gas chromatography-mass spectrometry analysis}

Gas chromatography-mass spectroscopy (GC-MS-QP2010 plus Shimadzu, Japan) system, is a very efficient technique commonly used for the identification and quantification of fatty acids in substances (Fig. 1) The unknown organic compounds in the complex mixture found in the oil were matched with the National Institute of Standards and Technology (NIST) library.

\section{Results and discussion}

Oil was extracted using normal hexane and chloroform in the ratio 50:50. The percentage oil yield from the seed of African star cherry was $23.80 \%$. The properties of the oil extracted are shown in Table 1. Figures 2 and 3 show the picture of African star apple seed and the ground seed respectively. The oil had a pleasant sweet smell, with honeylike colour and was semi solid at room temperature. Acid value of the oil was $17.41 \pm 0.43 \mathrm{mg} / \mathrm{KOH} / \mathrm{g}$, peroxide value was $57.74 \pm 2.77 \mathrm{meq} / \mathrm{kg}^{-1}$ and $8.75 \%$ free fatty acid. Also, iodine value of $29.00 \pm 0.16 \mathrm{mg} / 100 \mathrm{~g}$ and saponification value of $236.34 \pm 6.80 \mathrm{mg} / \mathrm{KOH} / \mathrm{g}$ were obtained for the oil. The percentage oil yield was low when compared to those reported earlier by researchers on oil seed such as $B$. parkii, (34.0\%), L. lanceolata (40.0\%), S. setegera (33.0\%) and S. birrea (42\%) and in agreement with the value B. sapida $(26.0 \%)$ but high when compared to the value of $D$. microcarpum (7.42\%) (Kyari, 2008), African star fruit (10.71\%) (Adebayo et al., 2012).

The acid value $(17.41 \pm 0.43 \mathrm{mg} / \mathrm{KOH} / \mathrm{g})$ of African star apple (ASA) was high when compared to the value of seed oil extracted from soursop $(1.82 \mathrm{mg} / \mathrm{KOH} / \mathrm{g}$ ) (Adepoju et al., 2014). Acid values less than $1 \%$ were reported by Kyari (2008). Subsequently, Adebayo et al. (2012), reported acid value of $4.50 \mathrm{mg} / \mathrm{KOH} / \mathrm{g}$ for African star fruit seed oil. Acid value is the measure of percentage content of free fatty acids in a substance, and degree of rancidity (Ononogbu, 2002). It is used as a parameter in determining freshness (Ononogbu, 2002). This implied high content of free fatty acid which could lead to high lipolytic activities, and a reduced shelf life.

Peroxide value (PV) of $57.74 \pm 2.77 \mathrm{meq} / \mathrm{kg}^{-1}$ was obtained. Peroxide value is an index of rancidity (Adebayo et al., 2012). The PV was high when compared to that $\left(1.57 \mathrm{meq} / \mathrm{kg}^{-1}\right)$ obtained by Adebayo et al. (2012). In the report of Kyari (2008) on six oil seeds, high PV of 77.5, 95.0, $150.0,135.0$ were obtained for B. parkii, L. lanceolata, D. microcarpum and B. sapida. Also, a low PV was reported by Adepoju et al. (2014) on their work on soursop seed oil. Free fatty acids FFA $(8.75 \%)$ was obtained in the study. The concentration of FFA in an oil is an important quality 


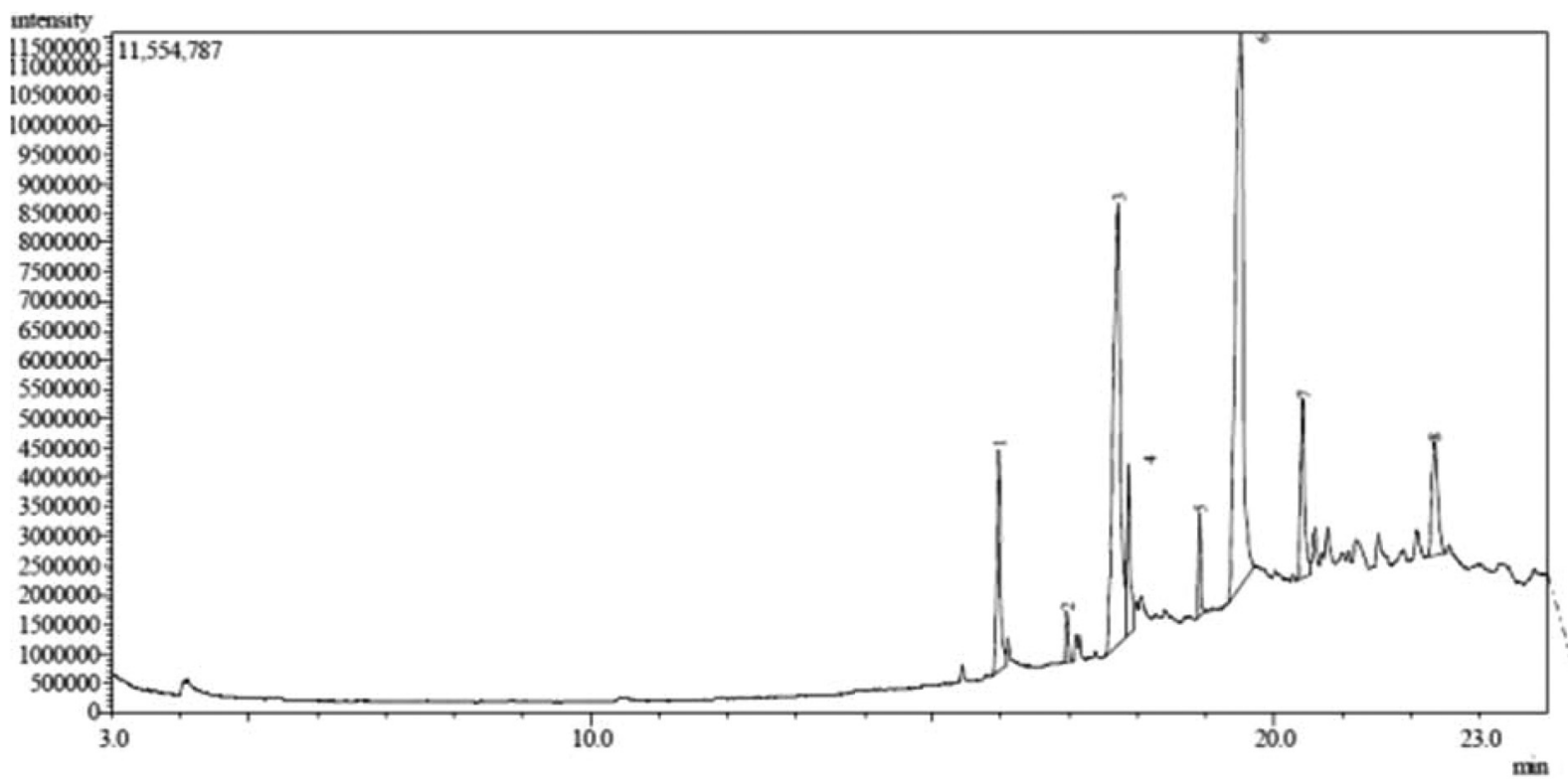

Fig. 1. Chromatogram of African star fruit seed oil.

Table 1. Characterization table of the extracted oil.

\begin{tabular}{ll}
\hline Parameters & Properties \\
\hline Odour & Pleasant \\
Colour & Honey-like \\
State at room temp. & Liquid \\
Acid value & $17.41 \pm 0.43 \mathrm{mg} / \mathrm{KOH} / \mathrm{g}^{-1}$ \\
Peroxide value & $57.74 \pm 2.77 \mathrm{meq} / \mathrm{kg}^{-1}$ \\
\% Free fatty acid & $8.75 \%$ \\
Iodine value & $29.00 \pm 0.16 \mathrm{~g} / 100 \mathrm{~g}$ \\
Saponification value & $236.341 \pm 6.80 \mathrm{mg} / \mathrm{KOH} / \mathrm{g}$ \\
\hline
\end{tabular}

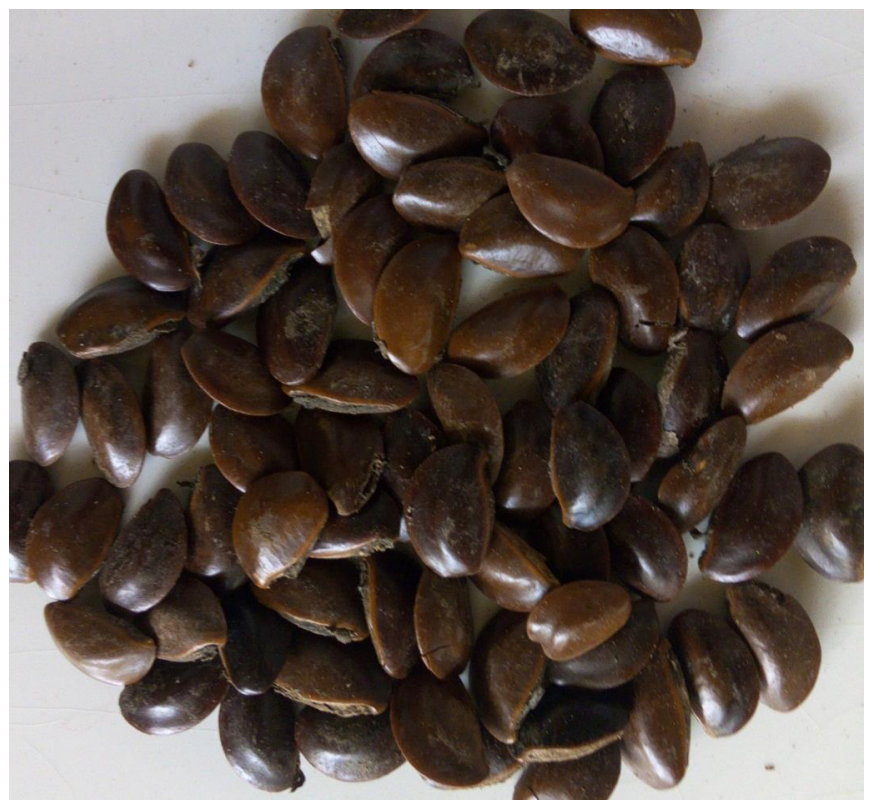

Fig. 2. African star apple seed (Chrysophyllum albidum).

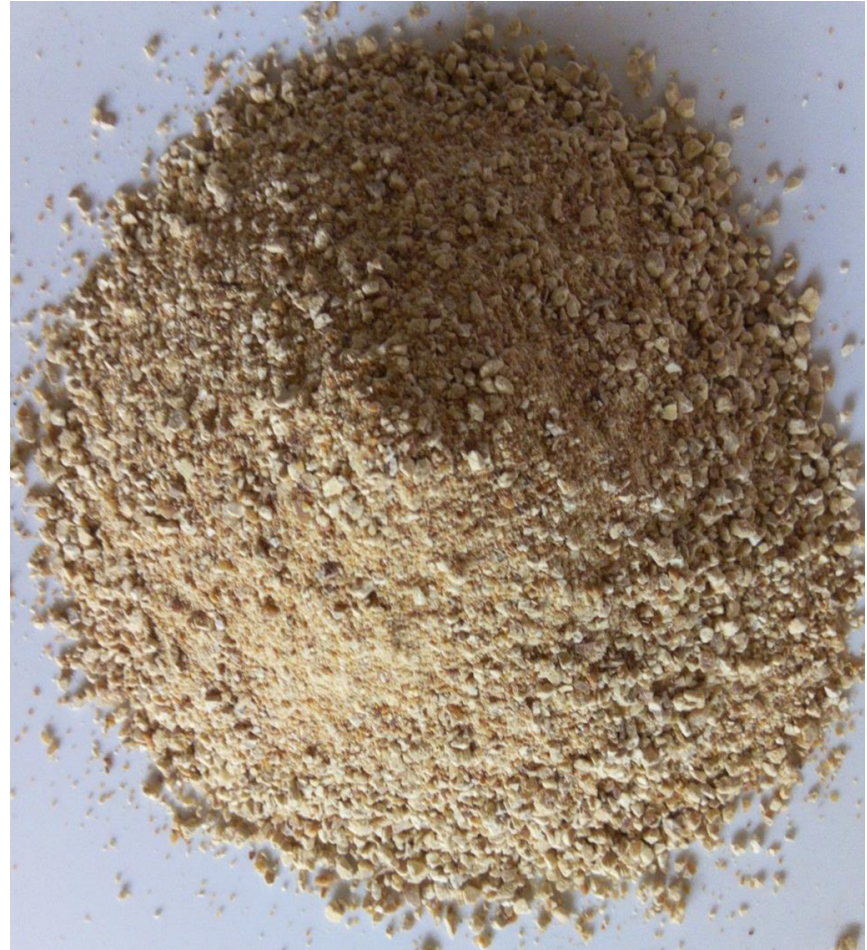

Fig. 3. The ground seed of African star apple.

parameter. Frega et al. (1999) reported that FFA added to refined oil shortened their induction time. Similarly, Scarpellini et al. (2005) also reported the prooxidant activity of FFA. Hence, it could be opined that high concentration of FFA could lead to short shelf life of oil. Adepoju et al. (2014) obtained FFA value of 0.91 for soursop seed oil. Also, Jatropha seed oil gave free fatty acid content $2.24 \%$. The high concentration of unsaturated free fatty acids showed that the oil could be prone to autoxidation; and high peroxide value suggest the seed oil 
Table 2. Fatty acids profile of the extracted African star fruit seed oil.

\begin{tabular}{|c|c|c|c|c|c|}
\hline Peaks & Name & Formulae & RT & MW & Area $(\%)$ \\
\hline 1 & n-hexadecanoic acid & $\mathrm{C}_{16} \mathrm{H}_{32} \mathrm{O}_{2}$ & 15.974 & 256 & 7.55 \\
\hline 2 & 13-hexyloxacyctri-dec 10 -en-2-one & $\mathrm{C}_{18} \mathrm{H}_{32} \mathrm{O}_{2}$ & 16.966 & 280 & 1.19 \\
\hline 4 & Octadecanoic acid & $\mathrm{C}_{18} \mathrm{H}_{36} \mathrm{O}_{2}$ & 17.868 & 284 & 5.28 \\
\hline 5 & Hexadecanoic acid & $\mathrm{C}_{19} \mathrm{H}_{38} \mathrm{O}_{2}$ & 18.907 & 330 & 2.37 \\
\hline 6 & Undecylenic acid & $\mathrm{C}_{11} \mathrm{H}_{20} \mathrm{O}_{2}$ & 19.512 & 184 & 40.33 \\
\hline 8 & 9, 17-octadecadienal & $\mathrm{C}_{18} \mathrm{H}_{32} \mathrm{O}$ & 22.345 & 264 & 5.98 \\
\hline
\end{tabular}

had high concentration of peroxide and hydro-peroxide which are primary products of autoxidation. The seed oil been rich in unsaturated fatty acids may be beneficial in the formulation of animal feeds and production of biodiesel.

Iodine value (IV) $29 \pm 0.16 \mathrm{~g} / 100 \mathrm{~g}$ was obtained in the work. It is the number of grams of iodine that combines with $100 \mathrm{~g}$ of lipids, which shows the degree of unsaturation of the fat or oil (Ononogbu, 2002), the oil is classified as a nondrying oil, and since its iodine value is less than 100 . This value is low when compared to $35 \mathrm{mg} / 100 \mathrm{~g}$ obtained by Adebayo et al. (2012). Also, the value is lower than all the six values obtained by Kyari (2008). The oil of soursop seed oil gave iodine value of $115.30 \mathrm{~g} / 100 \mathrm{~g}$ oil as reported by Adepoju et al. (2014). Also, the seed oil of C. albidum was reported to have iodine value of $31.06 \mathrm{~g} / 100 \mathrm{~g}$ by Osamudiamen and Afolabi (2014). The value was higher when compared to $29 \pm 0.16 \mathrm{~g} / 100 \mathrm{~g}$ obtained in this study.

Saponification value was another physicochemical analysis conducted on African star fruit seed oil. This is the number of milligram of $\mathrm{KOH}$ required to neutralize the fatty acids resulting from complex hydrolysis of $1 \mathrm{~g}$ of oil or fat (Ononogbu, 2002). Saponification value of $236.341 \pm 6.80 \mathrm{mg} /$ $\mathrm{KOH} /$ gram was obtained. This value conforms to the values of some vegetable oils used in soap making such as groundnut and coconut. Similarly, it is in agreement with the work of Kyari (2008) on B. sapidia, L. lanceolota, S. setegera and B. sapidia, but higher than the values of $D$. microcarpum and $S$. birrea which were 123.3 and $199.3 \mathrm{mg} / \mathrm{KOH} / \mathrm{g}$, respectively. Also, the result obtained in this work is higher when compared to the value 199.50 obtained by Adebayo et al. (2012) on ASC seed oil. Similarly, the saponification value is in agreement with that reported for soursop seed oil of $235.46 \mathrm{mg} / \mathrm{KOH} / \mathrm{g}$ (Adepoju et al., 2014).

Gas chromatography-mass spectrometry analysis (GC-MS) has been reported as an important tool for the identification and quantification of fatty acids (Shibula and Velavan, 2015; Okereke et al., 2017). The spectra of the study revealed eight peaks that corresponded to eight fatty acids and other organic substances present in the oil extracted from the seed of African star fruit. The compounds were confirmed by their retention time, percentage area, molecular weight and formulae, respectively. The major fatty acids revealed were undecylenic acid $(40.33 \%)$, oleic acid $(30.21 \%)$ and 9-octadecanal $(7.09 \%)$. Other identified fatty acids present included n-hexadecanoic acid (7.55\%), 13-hexyloxacyctri-dec-10-en-2-one (1.19\%), octadecanoic acid $(5.28 \%)$, hexadecanoic acid $(2.37 \%)$, undecylenic acid (40.33\%), 9-octadecanal (7.09\%), and 9, 17-octadecadienal $(5.98 \%)$ as shown in Table 2 . Similarly, Figure 1 showed eight peaks representing different fatty acids, with the concentration of undecylenic acid being highest as depicted by peak 6 . The concentration of undecylenic acid detected was higher when compared to the quantity (6.31\%) detected in P. americana seed oil as reported by Omeje et al. (2018). Avram et al. (2014) reported the presence oleic acid, linoleic acid and linolenic acid in the seed oil extracted from rapeseed using GC-MS. Gas chromatography analysis of fatty acids present in soursop seed oil revealed $73.42 \%$ of unsaturated fatty acid and $26.68 \%$ of saturated fatty acid (Adepoju et al., 2014). The physicochemical properties of the African star apple seed oil indicate it possess useful features of industrial oil which could be employed in food and chemical industries.

\section{Conclusion}

The percentage oil yield was $23.8 \%$. The extracted oil was liquid at room temperature, pleasant sweet smell with honey-like colour. African star fruit seed oil comprised of $85.74 \%$ fatty acids. Some of its physicochemical properties were good for industrial processes. African star fruit seed is non edible and a serious environmental waste which could be a source of oil which has a potential properties for applications in industries and other sectors of human endeavours.

\section{References}

Adebayo SE, Orhevba BA, Adeoye PA, Musa JJ, Fase OJ. 2012. Solvent extraction and characterization of oil from African star apple (C. albidum) seed. Acad Res Inter 3(2): 178-183.

Adepoju TF, Olawale O, Okunola AA, Olatunji EM. 2014. Solvent extraction of oil from soursop oilseeds and its quality characterization. Inter $J$ Sustain Energy Environ Res 3(2): 80-89.

Avram M, Stoica A, Dobre T, Streseu M. 2014. Extraction of vegetable oils from ground seeds by percolation techniques. $U P B$ Sci Bull Series B 76(2): 13-22.

Ehiagbonare JE, Onyibe HI, Okoegwale EE. 2008. Studies on the isolation of normal and abnormal seedlings of Chrysophyllum albidium; A step towards sustainable management of the taxon in the 21st century. Sci Res Essay 3(12): 567-570. 
Enechi OC. 2001. Basic biochemistry of food nutrients. Enugu, Nigeria: Immaculate Publications Ltd, pp. 23-27.

Frega N, Mozzon M, Lercker G. 1999. Effects of free fatty acids on oxidative stability of vegetable oil. J Amer Oil Chem Soc 76: 325-329.

Hamm W, Hamilton RJ, Calliauw G. 2013. Edible oil processing. 2nd Edition. Chichester UK: Wiley Blackwell Ltd., pp. 1-13.

Kyari MZ. 2008. Extraction and characterization of seed oils. Int Agrophysics 22: 139-142.

Oboh IO, Aluyor EO, Audu TOK. 2009. Use of Chrysophyllum albidum for the removal of metal ions from aqueous solution. $S c i$ Res Essay 4(6): 632-635.

Okereke SC, Arunsi UO, Nosiri CI. 2017. GC-MS/FT-IR screening of Xylopia aethiopica (Dunal) A. rich fruit. Afr J Biochem Res 11(3): 12-17.

Omeje KO, Ozioko JN, Opmeje HC. 2018. Pharmacological potentials, characterization and fatty acids profile of Persea americana mill. (avocardo) seed oil using gas chromatography-mass spectroscopy. Biochem Anal Biochem 7: 361. doi:10.4172/ 2161-1009.1000361.

Ononogbu IC. 2002. Lipids in human existence. Nsukka, Nigeria: AP Express Publishers, pp. 2-9.

Orsavova J, Misurcova L, Ambrozova JV, Vicha R, Mlcek J. 2015. Fatty acids composition of vegetable oils and its contribution to dietary energy intake and dependence of cardiovascular mortality on dietary intake of fatty acids. Int J Mol Sci 16: 12871-12890. doi:10.3390/ijms160612871.

Osamudiamen PM, Afolabi LO. 2014. Fatty acid composition of the seed oil of C. albidum (G. Don). Afr J Plant Sci 8(7): 364-365. doi:10.5897/AJPS2014.1154.

Scarpellini A, Cerretani L, Bendini A, Toschi TG. 2005. Effettodell'acidità libera sulla stabilità ossidativa di un olio neutralizzato. Ind Aliment 44: 22-25.

Shibula K, Velavan S. 2015. Determination of phytocomponents in methanolic extract of Annona muricata leaf using GC-MS technique. Int J Pharmacog Phytochem Res 7(6): 1251-1255.

Cite this article as: Omeje KO, Iroha OK, Edeke AA, Omeje HC, Apeh VO. 2019. Characterization and fatty acid profile analysis of oil extracted from unexploited seed of African star apple (Udara). OCL 26: 10. 